\title{
PENGARUH MEDIA AUDIO VISUAL INTERAKTIF DAN MOTIV ASI BELAJAR TERHADAP HASIL BELAJAR SISWA PADA MATA PELAJARAN PRAKARYA (Penelitian di Kelas XI MA Syekh Manshur)
}

\section{THE INFLUENCE OF INTERACTIVE AUDIO VISUAL MEDIA AND LEARNING MOTIVATION TOWARDS STUDENTS' LEARNING ACHIEVEMENTS ON HANDICRAFT SUBJECT (Study at Eleventh Grade of MA Syekh Manshur)}

\author{
AGUS HIDYATULLAH \\ Sekolah Tinggi Agama Islam Syekh Manshur \\ Jalan Raya Labuan Km 5 Kadulisung Pandeglang \\ Ponsel: 08128530123 \\ Surel: agushidayatullah1208@gmail.com
}

\begin{abstract}
Abstrak
Penelitian ini bertujuan untuk mengetahui pengaruh media audio visual interaktif dan motivasi belajar terhadap hasil belajar prakarya siswa kelas XI di MA Syekh Manshur. Metode penelitian yang digunakan yaitu eksperimen dengan desain faktorial, di mana satu variabel bebas terdiri atas dua dimensi, satu variabel moderator terdiri atas dua dimensi, dan satu variabel terikat. Hasil penelitian menunjukkan bahwa media audio visual interaktif memberikan nilai $F$ hitung 5,982 dan signifikansi 0,04 . Hal ini menunjukkan adanya perbedaan rerata hasil belajar. Motivasi memberikan nilai $F$ hitung sebesar 12,634 dan signifikansi 0,013 . Hal ini berarti terdapat perbedaan hasil belajar siswa kelas eksperimen dan kontrol. Hasil interaksi media audio visual interaktif dan motivasi belajar memberikan nilai $\mathrm{F}$ hitung sebesar 25,382 dan signifikansi 0,05 . Hal ini menunjukkan adanya pengaruh antara media audio visual interaktif dan motivasi belajar terhadap hasil belajar siswa.
\end{abstract}

Kata kunci: media audio visual, motivasi belajar, hasil belajar

\begin{abstract}
This study determines the influence of interactive audio visual media and learning motivation towards students' learning achievement on handicraft subject at eleventh grade of MA Syekh Manshur. This research conducted through experimental method with factorial design, which both independent and moderator variables consist of two dimensions, and one dependent variable. The result shows that interactive audio visual media has $F$ value of 5.982, and significance at 0.04 . It means the difference on mean scores of students' learning outcomes. Motivation shows $F$ value of 12.634 , and significance at 0.013 . This means the differences on learning achievement of experimental and control group. The results of interactive audio visual media and learning motivation show $F$ value of 25.382, and significance at 0.05 . This shows a significant influence between interactive audio visual media and learning motivation towards students' learning achievements.
\end{abstract}

Keywords: audio visual media, learning motivation, learning achievement 


\section{PENDAHULUAN}

Undang-Undang

Republik

Indonesia Nomor 20 Tahun 2003 menyampaikan bahwa salah satu dari sekian tujuan pendidikan adalah untuk mengembangkan potensi dan keterampilan siswa sehingga potensi dan keterampilan siswa semakin berkembang.

Dengan

berkembangnya potensi dan keterampilan siswa, maka berbagai bidang dalam kehidupan juga ikut berkembang.

Peningkatan kualitas proses dan hasil pembelajaran siswa di setiap jenjang pendidikan perlu diwujudkan agar diperoleh kualitas sumber daya manusia yang dapat menunjang pembangunan nasional. Dalam hal ini, peran seorang guru sangat penting dan menentukan, sebab gurulah yang terlibat langsung dalam membina dan mengajar para siswa di sekolah melalui proses pembelajaran.

Dalam sebuah proses
pembelajaran, seorang guru tentu
dituntut untuk menggunakan berbagai
metode maupun media yang dapat
meningkatkan kualitas proses
maupun hasil pembelajarannya.
Terkadang, metode pembelajaran tradisional yang lebih berpusat pada guru kurang menuntut siswa untuk berpartisipasi aktif. Karena itu, dalam rangka meningkatkan keaktifan siswa, guru sebaiknya memberi kegiatan yang lebih banyak memerlukan partisipasi siswa secara langsung. Seorang guru tidak hanya dituntut untuk membuat suasana pembelajaran menjadi nyaman dan menarik, tetapi juga harus mampu menciptakan media pembelajaran yang memudahkan siswa untuk memahami materi yang disampaikan.

Saat ini, banyak teknologi modern yang sudah digunakan oleh masyarakat. Baik itu televisi, radio, tape recorder, VCD, bahkan LCD dan komputer. Pada awalnya, teknologi seperti VCD, LCD, komputer adalah barang mewah yang jarang dimiliki masyarakat, tetapi saat ini telah menjadi barang umum untuk digunakan. Tidak hanya digunakan untuk konsumsi pribadi, hiburan atau digunakan kantor perusahaan, kini produk teknologi modern juga telah merambah di dunia pendidikan.

Adanya perkembangan ilmu pengetahuan dan teknologi juga akan berpengaruh terhadap kualitas sistem pembelajaran di sekolah. Dengan kehadiran teknologi modern, sekolah dituntut untuk cerdas dan kreatif dalam membuat pembelajaran menjadi lebih menarik, bermutu, efektif, dan efisien. 
Untuk mengembangkan potensi peserta didik juga sangat diperlukan inovasi dalam pembelajaran sehingga dapat menarik perhatian peserta didik. Banyak hal yang dapat dilakukan untuk membuat siswa tertarik dalam mengikuti proses pembelajaran, misalnya dengan menggunakan media pembelajaran yang sesuai dengan materi pelajaran. Sejalan dengan perkembangan zaman dan perkembangan teknologi, maka komputer dapat dijadikan salah satu media untuk membantu dalam proses pembelajaran.

Banyak ragam cara yang dapat dikembangkan dalam pembelajaran untuk melibatkan siswa aktif melalui stimulus media audio visual. Media audio visual dapat membantu peserta didik dalam proses pembelajaran. Media ini juga memungkinkan siswa lebih aktif dalam mengikuti pembelajaran. Selain itu, siswa tidak merasa bosan dengan menampilkan bentuk gambar bergerak dan juga suara yang bervariasi. Dengan penggunaan media pembelajaran audio visual berupa gambar bergerak dan suara yang bervariasi, siswa diharapkan dapat termotivasi dalam mengikuti proses pembelajaran.

Berbicara mengenai motivasi, entitas mental ini merupakan kekuatan yang mendorong seseorang melakukan sesuatu untuk mencapai tujuan. Seseorang yang memiliki motivasi untuk melakukan sesuatu cenderung memberikan perhatian yang lebih besar kepada obyek tersebut.

Begitu pula dalam proses pembelajaran, motivasi merupakan faktor yang memengaruhi keberhasilan dalam proses belajar. Jika seorang siswa memiliki motivasi belajar yang besar, siswa akan lebih cepat dalam memahami materi pembelajaran yang disampaikan. Selain itu, motivasi juga merupakan faktor utama yang menentukan keterlibatan siswa dalam belajar.

Berdasarkan hasil observasi pendahuluan, peneliti mendapati beberapa permasalahan yang muncul. (1) Pembelajaran yang berlangsung masih menggunakan lembar kerja siswa dan buku guru saja. (2) Media pembelajaran yang digunakan kurang bervariasi. (3) Beberapa siswa terlihat tidak antusias dalam belajar dan tidak memperhatikan guru. (4) Beberapa siswa sering sekali mengobrol dan sering keluar masuk kelas dengan alasan ingin ke kamar mandi. (5) Siswa merasa kesulitan memahami materi yang disampaikan, hal ini 
terlihat saat guru memberikan pertanyaan kepada siswa. Motivasi belajar siswa juga masih rendah. (7) Nilai rerata ulangan harian pada pelajaran prakarya belum mencapai hasil yang maksimal, hal ini dilihat dari 4 kelas XI di MA Syekh Manshur terdapat $56 \%$ siswa masih di bawah nilai KKM sekolah yang ditetapkan yaitu 7,5. Oleh karena itu, untuk meningkatkan nilai KKM siswa maka perlu adanya inovasi pembelajaran guna meningkatkan nilai khusunya mata pelajaran prakarya dengan melalui penerapan metode pembelajaran yang menarik seperti pembelajaran menggunakan media audio visual interaktif.

Dari uraian permasalahan di atas, peneliti berasumsi perlu diadakannya media pembelajaran yang mampu meningkatkan motivasi dan hasil belajar siswa. Oleh karena itu, peneliti tertarik untuk mengkaji hal tersebut dalam penelitian yang berjudul 'Pengaruh Media Audio Visual Interaktif dan Motivasi Belajar terhadap Hasil Belajar Siswa Pada Mata Pelajaran Prakarya Kelas XI MA Syekh Manshur.'

Kemudian, rumusan masalah dalam penelitian ini yaitu (1) Apakah terdapat perbedaan hasil belajar prakarya antara siswa yang belajar dengan menggunakan media audio visual interaktif dan pembelajaran konvensional pada siswa siswa kelas XI di MA Syekh Manshur? (2) Apakah terdapat perbedaan hasil belajar prakarya antara siswa yang memiliki motivasi tinggi dan siswa yang memilki motivasi rendah pada siswa siswa kelas XI di MA Syekh Manshur? (3) Apakah terdapat perbedaan yang signifikan hasil belajar prakarya antara siswa yang belajar menggunakan media audio visual interaktif dan pembelajaran konvensional untuk siswa yang miliki motivasi belajar tinggi pada siswa kelas XI di MA Syekh Manshur? (4) Apakah terdapat perbedaan yang signifikan hasil belajar prakarya antara siswa yang belajar menggunakan media audio visual interaktif dan pembelajaran konvensional untuk siswa yang miliki motivasi belajar rendah pada siswa kelas XI di MA Syekh Manshur? (5) Apakah terdapat pengaruh interaksi antara pembelajaran dengan menggunakan (media audio visual interaktif dan konvensional) dan motivasi belajar prakarya terhadap hasil belajar prakarya siswa kelas $\mathrm{XI}$ di MA Syekh Manshur?

Tujuan yang hendak dicapai dalam penelitian ini yaitu (1) Ingin 
mengetahui perbedaan hasil belajar prakarya antara siswa yang belajar dengan menggunakan media audio visual interaktif dan pembelajaran konvensional pada siswa siswa kelas XI di MA Syekh Manshur. (2) Ingin mengetahui perbedaan hasil belajar prakarya antara siswa yang memiliki motivasi tinggi dan siswa yang memilki motivasi rendah pada siswa kelas XI di MA Syekh Manshur. (3) ingin mengetahui perbedaan yang signifikan hasil belajar prakarya antara siswa yang belajar menggunakan media audio visual interaktif dan pembelajaran konvensional untuk siswa yang miliki motivasi belajar tinggi pada siswa kelas XI di MA Syekh Manshur. (4) Ingin mengetahui perbedaan yang signifikan hasil belajar prakarya antara siswa yang belajar menggunakan Media audio visual interaktif dan pembelajaran konvensional untuk siswa yang miliki motivasi belajar rendah pada siswa kelas XI di MA Syekh Manshur. (5) Ingin mengetahui pengaruh interaksi antara pembelajaran dengan menggunakan (Media audio visual interaktif dan konvensional) dan motivasi belajar prakarya terhadap hasil belajar prakarya siswa kelas XI di MA Syekh Manshur.

\section{KAJIAN TEORETIK}

Hasil belajar adalah pola-pola perbuatan, nilai-nilai, pengertianpengertian, sikap-sikap, apresiasi dan keterampilan yang berupa: (1) informasi verbal yaitu kapabilitas mengungkapkan pengetahuan dalam bentuk bahasa, baik lisan maupun tertulis, (2) keterampilan intelektual yaitu kemampuan mempresentasikan konsep dan lambang atau kemampuan melakukan aktivitas kognitif bersifat khas, (3) strategi kognitif yaitu kecakapan menyalurkan dan mengarahkan aktivitas kognitifnya sendiri, (4) keterampilan motorik yaitu kemampuan melakukan serangakaian gerak jasmani, dan (5) sikap adalah kemampuan menginternalisasi dan mengeksternalisasi nilai-nilai (Suprijono, 2010: 6). Karena itu, Seorang pendidik bertugas mendorong peserta didik agar belajar secara berhasil, tetapi keadaan peserta didik yang bermacam-macam menggambarkan bahwa pengetahuan tentang masalah-masalah yang muncul dalam pembelajaran merupakan hal yang sangat penting bagi guru.

Belajar merupakan suatu kegiatan yang hasilnya dipengaruhi oleh bermacam-macam faktor, baik dari faktor dalam diri sendiri atau 
faktor dari luar. Adapun hasil belajar yang dipengaruhi oleh media visual dan audio visual, khususnya teknologi informasi, sangat berpengaruh terhadap penyusunan dan implementasi strategi pembelajaran. Melalui kemajuan tersebut para guru dapat menggunakan berbagai media sesuai dengan kebutuhan dan tujuan pembelajaran.

Proses pembelajaran merupakan proses komunikasi. Dalam suatu proses komunikasi selalu melibatkan tiga komponen pokok, yaitu komponen pengirim pesan (guru), komponen penerima pesan (siswa), dan komponen pesan itu sendiri yang biasanya berupa materi pelajaran. Kadang-kadang dalam proses pembelajaran terjadi kegagalan komunikasi. Untuk menghindarinya, seorang guru dapat menyusun strategi pembelajaran dengan memanfaatkan berbagai media dan sumber belajar (Sanjaya, 2006: 160). Media pembelajaran sejatinya merupakan segala bentuk baik berupa manusia, materi atau kejadian yang membangun kondisi tertentu sebagai sarana perantara dalam proses pembelajaran untuk mencapai suatu tujuan pembelajaran yang memiliki manfaat yaitu dapat memperjelas pesan agar tidak terlalu verbalistis, mengatasi keterbatasan, memberi rangsangan yang dapat menyamakan pemahaman siswa serta dapat memberikan pembelajaran yang efektif dan efisien. Sedangkan motivasi belajar merupakan salah satu faktor yang turut menentukan keefektifan dalam pembelajaran. Seorang peserta didik akan belajar dengan baik apabila ada faktor pendorongnya yaitu motivasi belajar. Peserta didik akan belajar dengan sungguh-sungguh jika memiliki motivasi belajar yang tinggi.

Ada peran penting dalam motivasi belajar sebagaimana dikatakan Uno (2011: 27-29) antara lain: (1) peran motivasi belajar dalam menentukan penguatan belajar, (2) peran motivasi dalam memperjelas tujuan belajar, dan (3) motivasi menentukan ketekunan belajar. Seorang anak yang telah termotivasi untuk belajar sesuatu berusaha mempelajari dengan baik dan tekun dengan harapan memperoleh hasil yang lebih baik. Menurut Slameto (2010: 26), motivasi belajar dipengaruhi oleh tiga komponen, yaitu: (1) dorongan kognitif, yaitu kebutuhan untuk mengetahuhi, mengerti, dan memecahkan masalah, (2) harga diri, yaitu ada siswa tertentu yang tekun belajar dan melaksanakan 
tugas-tugas bukan terutama untuk memperoleh pengetahuan atau kecakapan, tetapi untuk memperoleh status dan harga diri, (3) kebutuhan berafiliasi, yaitu kebutuhan untuk menguasai bahan pelajaran/ belajar dengan niat guna mendapatkan pembenaran dari orang lain/ temanteman. Setiap motivasi belajar memiliki tujuan secara umum, motivasi bertujuan menggerakkan seseorang agar timbul keinginan dan kemauan untuk melakukan sesuatu sehingga dapat memperoleh hasil atau mencapai tujuan tertentu.

\section{METODE PENELITIAN}

Penelitian ini dilaksanakan di MA Syekh Manshur Pandeglang yang beralamat di Kampung Kalahang Masjid RT. 08 RW. 03 Desa Kadu Dodol Kecamatan Cimanuk Kabupaten Pandeglang Banten. Waktu penelitian dilakukan pada Oktober sampai Desember 2018. Sampel penelitian adalah siswa kelas XI MA Syekh Manshur tahun pelajaran 2018/2019 yang terdiri atas 2 kelas berjumlah 44 orang.

Uji validitas dalam penelitian ini dengan menggunakan SPSS 20 for windows. Sedangkan Uji reliabilitas dalam penelitian ini menggunakan Cronbach's Alpha.
Analisis data yang digunakan yaitu melalui analisis uji prasyarat pengujian hipotesis dengan uji normalitas menggunakan SPSS (Kolmogorov Smirnov Z). Uji homogenitas varian dengan menggunakan SPSS (One Sample Kolmogorov Smirnov Test). ANOVA dua jalur 2x2 digunakan untuk menguji analisis pengaruh penggunaan media audio visual Interaktif dan motivasi terhadap hasil belajar siswa.

\section{HASIL DAN PEMBAHASAN}

Setelah dilakukan analisis dengan menggunakan rumus uji-t independent sample tes, maka didapatkan hasil nilai t adalah 5,866, Dengan membandingkan besarnya nilai t dari perhitungan data dan besar t tabel maka dapat diketahui bahwa t hitung $>$ t tabel yaitu: 5,866 >1,681. Hasil t hitung lebih besar dari $t$ tabel, maka hipotesis nol ditolak, hal ini berarti terdapat perbedaan yang signifikan hasil belajar prakarya antara siswa dengan yang menggunakan Media audio visual interaktif dan yang menggunakan metode konvensional.

Uji perbedaan hasil belajar prakarya antara siswa yang memiliki motivasi tinggi dengan siswa yang 
memiliki motivasi rendah pada kelas XI di MA Syekh Manshur yaitu dengan uji-t independent sample tes, maka didapatkan hasil nilai $t$ adalah 1,925, sedangkan nilai t tabel dk 42 (Dk $=\mathrm{n} 1+\mathrm{n} 2-2=44-2=42$ ) dengan taraf signifikasi 5\% adalah: 1,681. Dengan membandingkan besarnya nilai $t$ dari perhitungan data dan besar $t$ tabel maka dapat diketahui bahwa t hitung $>t$ tabel yaitu: 1,925 >1,681. Hasil $t$ hitung lebih besar dari t tabel, maka hipotesis nol ditolak. Hal ini berarti terdapat perbedaan yang signifikan hasil belajar prakarya antara siswa dengan motivasi tinggi dengan siswa motivasi rendah.

Dengan perbedaan yang signifikan dari hasil belajar prakarya antara siswa yang belajar menggunakan media audio visual interaktif dan pembelajaran konvensional untuk siswa yang miliki motivasi belajar tinggi pada siswa kelas XI di MA Syekh Manshur harus dilakukan analisis dengan menggunakan rumus uji-t independent sample tes, maka didapatkan hasil nilai $t$ adalah 5,460, sedangkan nilai $\mathrm{t}$ tabel $\mathrm{dk} 30$ (Dk $=n 1+n 2-2=32-2=30$ ) dengan taraf signifikasi 5\% adalah: 1,697. Dengan membandingkan besarnya nilai $t$ dari perhitungan data dan besar $t$ tabel maka dapat diketahui bahwa t hitung $>t$ tabel yaitu: $5,460>1,697$. Hasil $t$ hitung lebih besar dari t tabel, maka hipotesis nol ditolak. Hal ini berarti terdapat perbedaan yang signifikan antara hasil belajar pembelajaran dengan menggunakan media audio visual interaktif dan pembelajaran konvensional untuk siswa yang miliki motivasi belajar tinggi pada siswa kelas XI di MA Syekh Manshur.

Uji perbedaan yang signifikan hasil belajar prakarya antara siswa yang diajari menggunakan media audio visual interaktif dan pembelajaran konvensional untuk siswa yang miliki motivasi belajar rendah pada siswa kelas XI di MA Syekh Manshur dianalisis dengan menggunakan rumus uji-tindependent sample tes, maka didapatkan hasil nilai $t$ adalah 2,394, sedangkan nilai $t$ tabel dk 10 (Dk =n1+n2-2 =12-2=10) dengan taraf signifikasi $5 \%$ adalah: 1,812. Dengan membandingkan besarnya nilai $t$ dari perhitungan data dan besar $t$ tabel maka dapat diketahui bahwa $\mathrm{t}$ hitung $>\mathrm{t}$ tabel yaitu: $2,394>1,812$. Hasil t hitung lebih besar dari $t$ tabel, maka hipotesis nol ditolak. Hal ini berarti terdapat perbedaan yang signifikan hasil belajar pembelajaran dengan menggunakan Media Audio Visual 
Interaktif dan pembelajaran konvensional untuk siswa yang miliki motivasi belajar rendah pada siswa kelas XI di MA Syekh Manshur.

Uji pengaruh interaksi antara pembelajaran dengan menggunakan (Media audio visual interaktif dan konvensional) dan motivasi belajar prakarya terhadap hasil belajar prakarya siswa kelas XI di MA Syekh Manshur diketahui terdapat pengaruh langsung antara penggunaan Media audio visual interaktif dan motivasi belajar. Penggunaan Media audio visual interaktif memberikan nilai $F$ hitung 5,982 dan signifikan pada 0,04 hal ini berarti terdapat perbedaan rata-rata hasil belajar. Motivasi memberikan nilai $F$ hitung sebesar 12,634 dan signifikan pada 0,013. Hal ini berarti terdapat perbedaan hasi belajar yang diperoleh siswa kelas eksperime dan kontrol. Hasil interaksi Media audio visual interaktif dan motivasi belajar memberikan nilai $F$ hitung sebesar 25,382 dan signifikan pada 0,05 . Hal ini berarti terdapat pengaruh antara media audio visual interaktif dan motivasi belajar terhadap hasil belajar siswa.

\section{SIMPULAN}

Berdasarkan pembahasan di atas, dapat disampaikan beberapa simpulan sebagaimana berikut. Pertama, terdapat perbedaan yang signifikan hasil belajar prakarya antara siswa yang menggunakan media audio visual interaktif dan yang menggunakan media pembelajaran konvensional. Kedua, terdapat perbedaan yang signifikan hasil belajar prakarya siswa antara siswa dengan motivasi tinggi dan siswa dengan motivasi rendah. Kemudian, terdapat perbedaan yang signifikan hasil belajar prakarya antara siswa yang belajar menggunakan media audio visual interaktif dan menggunakan media pembelajaran konvensional untuk siswa yang miliki motivasi belajar tinggi. Keempat, terdapat perbedaan yang signifikan hasil belajar prakarya antara siswa yang belajar menggunakan media audio visual interaktif dan pembelajaran konvensional untuk siswa yang miliki motivasi belajar rendah. Terakhir, terdapat pengaruh interaksi antara pembelajaran dengan menggunakan media audio visual interaktif dan konvensional dan motivasi belajar terhadap hasil belajar.

Terakhir, saran yang dapat disampaikan di antaranya bahwa seorang guru hendaknya menggunakan media audio visual 
karena mampu meningkatkan

motivasi dan hasil belajar siswa.

Kemudian, media audio visual harus

mampu digunakan oleh guru pada standar kompetensi yang lain agar tujuan pembelajaran dapat dicapai dengan maksimal.

\section{DAFTAR PUSTAKA}

Sanjaya, Wina. Strategi Pembelajaran Berorientasi Standar Proses

Pendidikan. Jakarta: Kencana

Prenada Media, 2006.

Slameto. Belajar dan Faktor-faktor yang Mempengaruhinya. Jakarta: Rineka Cipta, 2010.

Suprijono, Agus. Pembelajaran Kooperatif. Yogyakarta: Pustaka Pelajar, 2010.

Uno, B., Hamzah. Teori Motivasi dan Pengukurannya. Jakarta: Bumi Aksara, 2011. 